NBER WORKING PAPER SERIES

IMMIGRATION IN HIGH-SKILL LABOR MARKETS: THE IMPACT OF FOREIGN STUDENTS ON THE EARNINGS OF DOCTORATES

\author{
George J. Borjas \\ Working Paper 12085 \\ http://www.nber.org/papers/w12085 \\ NATIONAL BUREAU OF ECONOMIC RESEARCH \\ 1050 Massachusetts Avenue \\ Cambridge, MA 02138 \\ March 2006
}

Robert W. Scrivner Professor of Economics and Social Policy, John F. Kennedy School of Government, Harvard University; and Research Associate, National Bureau of Economic Research. I am grateful to Alberto Abadie, Ronald Ehrenberg, Richard Freeman, Rachel Friedberg, and Paula Stephan for helpful suggestions, and to the Sloan Foundation for research support. The views expressed herein are those of the author(s) and do not necessarily reflect the views of the National Bureau of Economic Research.

C2006 by George J. Borjas. All rights reserved. Short sections of text, not to exceed two paragraphs, may be quoted without explicit permission provided that full credit, including $₫$ notice, is given to the source. 
Immigration in High-Skill Labor Markets: The Impact of Foreign Students on the Earnings of Doctorates

George J. Borjas

NBER Working Paper No. 12085

March 2006

JEL No. J23, J61

\begin{abstract}
$\underline{\text { ABSTRACT }}$
The rapid growth in the number of foreign students enrolled in American universities has transformed the higher education system, particularly at the graduate level. Many of these newly minted doctorates remain in the United States after receiving their doctoral degrees, so that the foreign student influx can have a significant impact in the labor market for high-skill workers. Using data drawn from the Survey of Earned Doctorates and the Survey of Doctoral Recipients, the study shows that a foreign student influx into a particular doctoral field at a particular time had a significant and adverse effect on the earnings of doctorates in that field who graduated at roughly the same time. A 10 percent immigration-induced increase in the supply of doctorates lowers the wage of competing workers by about 3 to 4 percent. About half of this adverse wage effect can be attributed to the increased prevalence of low-pay postdoctoral appointments in fields that have softer labor market conditions because of large-scale immigration.

George J. Borjas

Kennedy School of Government

Harvard University

79 JFK Street

Cambridge, MA 02138

and NBER

gborjas@harvard.edu
\end{abstract}




\title{
IMMIGRATION IN HIGH-SKILL LABOR MARKETS: THE IMPACT OF FOREIGN STUDENTS ON THE EARNINGS OF DOCTORATES
}

\author{
George J. Borjas*
}

\section{Introduction}

The rapid growth in the number of foreign students enrolled in American universities has transformed the higher education system, particularly at the graduate level. In 1976, 72.4 thousand foreign students were enrolled in graduate programs, making up 5.5 percent of total enrollment. By 2000, 232.3 thousand foreign students were enrolled, or 12.6 percent of enrollment. The impact is even greater at the doctoral level. For example, the fraction of doctoral degrees awarded to foreign students rose from 11.3 to 24.4 percent during the same period, with nonresident aliens receiving a remarkably high share of the doctoral degrees awarded in the physical sciences (36.5 percent of all doctorates awarded in 2000), engineering (50.7 percent), and the life sciences $(25.7$ percent $){ }^{1}$

Many of these newly minted doctorates remain in the United States after receiving their doctoral degrees, so that the foreign student influx can have a significant impact in the labor market for high-skill workers. ${ }^{2}$ Despite the large size of the supply shock and despite the importance of the labor market for doctorates in determining technological change and economic growth, there has not been any study of how the foreign student program affects labor market

\footnotetext{
* Robert W. Scrivner Professor of Economics and Social Policy, John F. Kennedy School of Government, Harvard University; and Research Associate, National Bureau of Economic Research. I am grateful to Alberto Abadie, Ronald Ehrenberg, Richard Freeman, Rachel Friedberg, and Paula Stephan for helpful suggestions, and to the Sloan Foundation for research support.

1 U.S. Department of Education (2002), Tables 207, 270, 272.

${ }^{2}$ Finn (2003) calculates the stay rate of foreign-born doctoral recipients. The proportion of foreign-born doctorates who remain in the United States after receiving their degree increased from 49 percent for the 1989 cohort to 71 percent for the 2001 cohort.
} 
conditions for high-skill workers. ${ }^{3}$ This paper provides an initial attempt to address a question that inevitably lies at the core of any evaluation of the costs and benefits of the foreign student program: Has the foreign student influx into doctoral programs harmed the economic opportunities of competing native workers?

There already exists a large literature in labor economics that attempts to analyze the labor market impact of immigration. This literature, however, has been in a state of flux and confusion for many years. The simplest supply-demand framework implies that "limitation of the supply of any grade of labor relative to all other productive factors can be expected to raise its wage rate; an increase in supply will, other things being equal, tend to depress wage rates" (Samuelson, 1964, p. 552). Despite the intuitive appeal of these theoretical implications, and despite the large number of careful studies in the literature, it has proved surprisingly difficult to demonstrate empirically that immigration has a sizable and significant adverse effect on competing workers. For example, a widely cited survey by Friedberg and Hunt (1995, p. 42) concludes that "the effect of immigration on the labor market outcomes of natives is small."4 This conclusion is difficult to reconcile with the textbook model because the immigrant supply shock in recent decades has been very large, and most studies of labor demand (outside the immigration context) conclude that the labor demand curve is not perfectly elastic (Hamermesh, 1993).

Much of the existing literature exploits the fact that immigrants in the United States cluster in a small number of geographic areas and uses the geographic variation in the supply

\footnotetext{
${ }^{3}$ Freeman $(1975,1976)$ used a cobweb model to analyze how wages adjust to supply shifts in high-skill labor markets. Because Freeman studied the supply shifts that occurred between the late 1940s and the early 1970s, he did not address the question of how these markets responded to immigration-induced supply shifts.

${ }^{4}$ Borjas (1999) and Smith and Edmonston (1997) also survey the literature and reach the same conclusion.
} 
shock to identify the labor market impact of immigration. ${ }^{5}$ The stereotypical study defines a metropolitan area as the labor market that is being penetrated by immigrants. The study then goes on to measure the relation between the native wage in the locality and the relative number of immigrants in that locality. Although there is a great deal of dispersion across studies, the estimated correlations tend to cluster around zero, and this finding is often interpreted as saying that immigrants have little impact on the labor market opportunities of native workers.

Recent research raises two questions about the validity of this interpretation of the evidence. First, immigrants may not be randomly distributed across local labor markets. If immigrants tend to endogenously cluster in cities with thriving economies, there would be a spurious positive correlation between immigration and local outcomes. Second, natives may respond to the immigrant supply shock in a local labor market by moving their labor or capital to other cities. These flows of internal migrants or capital would re-equilibrate the national labor market and "spread out" the impact of immigration over the entire economy. A comparison of the economic opportunities facing native workers in different cities would show little or no difference because, in the end, immigration affected every city, not just the ones that actually received immigrants. ${ }^{6}$

Because of the strong likelihood that the local labor market adjusts to immigrationthrough the internal migration of workers or jobs—recent studies have proposed changing the unit of analysis to the national level. Borjas (2003), for example, examines the evolution of the

${ }^{5}$ Representative studies include Altonji and Card (1991), Card (1990), Grossman (1982), LaLonde and Topel (1991), and Schoeni (1997). Friedberg (2001) presents a rare study that uses the supply shock in an occupation to identify the labor market impact of immigration in the Israeli labor market. Card (2001) uses data on occupation and metropolitan area to define the relevant labor markets and estimates a slight adverse impact of an immigration-induced supply increase. 
national wage structure for skill groups defined in terms of educational attainment and work experience. ${ }^{7}$ The use of work experience to classify workers across skill groups takes advantage of the notion that similarly educated workers with similar levels of experience are more likely to be substitutable with each other than similarly educated workers with very different levels of experience (Welch, 1979; Card and Lemieux, 2001). The empirical analysis reported in Borjas (2003) used Census data from 1960 through 2000 and indicated that immigration indeed harmed the earnings opportunities of competing native workers. An immigrant influx that increases the size of a particular skill group by 10 percent lowers the wage of native workers in that group by about 3 to 4 percent.

This paper uses data drawn from the Survey of Earned Doctorates and the Survey of Doctoral Recipients to analyze the impact of the influx of foreign students on the earnings of doctorates. ${ }^{8}$ These data provide detailed information on the size of the immigrant supply shock and the labor market experiences of doctorates in science and engineering. The data also contain information on doctoral fields and year of graduation, so that it is possible to construct specific cohorts of doctorates and examine how a particular supply shock affects the earnings of doctorates in that cohort. It turns out that the foreign student influx has differentially affected

\footnotetext{
${ }^{6}$ Borjas, Freeman, and Katz (1997) and Card (2001) provide the first attempts to jointly analyze labor market outcomes and native migration decisions.

${ }^{7}$ See also Borjas, Freeman, and Katz (1997).

${ }^{8}$ The labor market impact of the foreign student influx has not been examined in the existing literature even though the wage of doctorates is a crucial indicator of conditions in high-skill labor markets and is a major part of the costs of running universities or firms engaged in research and development (Ehrenberg, 2000). A related study by Levin et al (2004) uses a "shift-share" methodology to analyze employment patterns of native- and foreign-born doctorates in science and engineering and finds that native-born doctorates are under-represented in those fields most heavily penetrated by foreign students.
} 
different fields at different times. I exploit this variation in the supply shock to identify the impact of immigration on high-skill labor markets.

In an important sense, the foreign student influx into the labor market for doctorates provides a near-ideal research framework for measuring the impact of immigration. The labor market for these high-skill workers is certainly national (and perhaps even international) in scope. It is also unlikely that the internal migration of doctorates across fields can help the highskill labor market adjust to the supply shocks. A doctoral education in science and engineering is a highly specialized endeavor, requiring the investment of a great deal of time and effort, and the training is very specific. ${ }^{9}$ An exogenous supply increase in a particular field at a particular time may affect the education decisions of future generations of students, but there is relatively little that current doctorates can do about the situation except to absorb the supply shock—presumably through lower wages.

The empirical analysis reported in this paper clearly shows that a foreign student influx into a particular field at a particular time has a significant and adverse effect on the earnings of competing doctorates in that field who graduated at roughly the same time. A 10 percent immigration-induced increase in the supply of doctorates lowers the wage of competing workers by about 3 to 4 percent—remarkably similar to the elasticity estimates reported in Borjas (2003) for the typical worker in the national labor market. About half of this adverse wage effect can be attributed to the increased prevalence of low-pay postdoctoral appointments in fields where immigration has softened labor market conditions. Because the magnitude of the immigrant supply shock in particular fields has been sizable, this elasticity implies that many doctorates

\footnotetext{
${ }^{9}$ The notion that labor supply is inelastic in the short run was a core assumption of the cobweb model used by Freeman $(1975,1976)$ to interpret wage and employment adjustments in high-skill labor markets.
} 
employed in the United States, whether native-born or foreign-born, have experienced a substantial wage loss.

\section{Data}

The analysis uses data drawn from the Survey of Earned Doctorates (SED) and the Survey of Doctoral Recipients (SDR). These data files, designed to provide detailed information on trends in the number of doctorates awarded and in labor market conditions for these high-skill workers, are maintained by the National Science Foundation. ${ }^{10}$

The SED provides a population census of all persons who receive doctorates from a U.S. institution in a particular calendar year, with a response rate of around 92 percent. I will use the SED to calculate the magnitude of the immigrant supply shock by field and year of degree. The SDR is a biennial longitudinal file that provides a 7 percent sample of persons who obtained their doctoral degrees in the United States in science or engineering, and contains detailed information on a worker's employment and earnings. A sample of newly granted doctorates is added to the sample every two years and a "maintenance cut" of older doctorates is conducted so as to keep sample size relatively constant at around 30,000 per wave. The existing panel consists of five waves, beginning in $1993 .{ }^{11}$ The analysis reported below will use data from all of the five panels conducted between 1993 and 2001. By linking the two data sets, it is possible to ascertain if

\footnotetext{
10 The National Science Foundation has two websites that provide detailed descriptions of the SED and SDR data sets. The SED website is http://www.nsf.gov/sbe/srs/ssed/sedmeth.htm; and the SDR website is http://sestat.nsf.gov. The data analyzed in this paper are available from the NSF under a licensing agreement designed to guard the confidentiality of the survey participants.

11 The SDR actually dates back before 1993, but there was a major redesign of the sample in the early 1990s that makes it extremely difficult to longitudinally track persons before and after 1993. The sample redesign was prompted by the fact that the response rate had fallen to around 50 percent by the late 1980 s, probably making the data collected by the SDR prior to 1993 quite unrepresentative of the underlying population.
} 
immigrant supply shocks specific to a particular cohort defined by field and year of graduation affected the labor market performance of competing workers.

I restrict the analysis to persons who received their doctoral degree between 1968 and 2000. The SED did not collect data that identified a person's detailed immigration status (such as the difference between a naturalized citizen or a native-born citizen) prior to 1967. After 1967, the "citizenship status" variable reports if the newly minted doctorate was a native-born citizen, a naturalized citizen, a non-citizen with a permanent visa, or a non-citizen with a temporary visa at the time the degree was awarded. Throughout the analysis, I define an "immigrant" to be a person who is either a naturalized citizen or a non-citizen; all other persons are classified as "natives." Because the SDR data contains information on labor market characteristics of doctorates only in science and engineering, I restrict the analysis of the SED data to those persons who received doctoral degrees in those fields.

Consider the population of persons who are granted a doctorate in field $f$ in calendar year $c$. The foreign-born share in this particular field-cohort cell is given by:

$$
p_{f c}=\frac{M_{f c}}{M_{f c}+N_{f c}},
$$

where $M_{f c}$ gives the number of immigrants in cell $(f, c)$ and $N_{f c}$ gives the corresponding number of natives.

The top panel of Figure 1 shows the trend in the number of doctorates granted each year to native-born and foreign-born students (aggregated across all fields), while the bottom panel of the figure shows the trend in the aggregate immigrant share. The annual number of doctorates granted to native students in science and engineering declined from about 16 thousand in 1970 to 
about 14 thousand in 1980. It then began a slow steady rise that lasted through the late 1990s. By the late 1990s, around 18 thousand native persons were being granted doctorates in science and engineering each year.

The figure also shows that there was an even steeper rise in the number of doctorates granted to immigrants. Between 1980 and 1995, the number of doctorates granted to persons that I have classified as immigrants rose from about 4 thousand to almost 11 thousand. As a result, the immigrant share in the number of doctorates awarded each year rose rapidly over the period. It was 17.5 percent in 1968 , peaked at 39.7 percent in 1994 , and then fell to 34.8 percent by 2000.

As noted above, the SED reports the person's citizenship and visa status at the time the doctorate was awarded. The timing of this information makes it impossible to ascertain exactly if the foreign-born doctorate entered the United States using a foreign student (temporary) visa. Nevertheless, it is likely that the overwhelming majority of these foreign-born doctorates entered the country using a student visa.

Table 1 shows that 76.7 percent of all doctorates granted between 1968 and 2000 to foreign-born students were granted to students who had temporary visas at the time the doctoral degree was awarded. Moreover, it is possible that many of the students who had permanent status at the time the doctorate was awarded entered the country with a student visa but then adjusted their status to get a "green card" (e.g., through marriage to a U.S. citizen) or became naturalized citizens. As Table 1 also shows, the fraction of foreign-born students who received their high school diploma abroad is over 95 percent both for foreign students with permanent status and with temporary visas. Put differently, it seems very likely that the bulk of the foreign- 
born population receiving their doctoral degrees from a U.S. university initially entered the country using a foreign student visa.

It is important to stress that not all of the immigrants granted doctorates by U.S. universities will influence conditions in the U.S. labor market (at least directly). Many of these newly minted doctorates will instead return to their home countries. It turns out, however, that the vast majority of foreign-born students - regardless of whether they have permanent status or a temporary visa at the time they receive their doctoral degree-intend to stay in the United States. The SED asks the newly minted doctorates if they intend "to live, work or study in the United States or a foreign country after receiving the doctorate." The bottom row of Table 1 shows that 64.3 percent of the foreign students with a temporary visa intend to remain in the United States and that over 90 percent who are citizens or have a permanent residence visa will also stay. ${ }^{12}$ In short, the foreign student program is an important conduit for supply shocks that permanently increase the number of doctoral workers in the United States.

I calculated an alternative measure of the immigrant supply shock for each field-cohort cell by using the information on whether the foreign student intends to stay in the United States after graduation. If these expectations are actually realized, the immigrant share that would be observed (and would determine conditions) in the U.S. labor market is given by:

$$
p_{f c}^{*}=\frac{M_{f c}^{*}}{M_{f c}^{*}+N_{f c}},
$$

12 Finn (2003) provides a detailed analysis of the trends in the stay rate for foreign-born doctorates. 
where $M_{f c}^{*}$ is the number of foreign-born doctorates that intend to stay in the United States.

The two panels of Figure 1 also illustrate the trend in the number of foreign-born doctorates and the immigrant share that includes only the "stayers." The supply shock to the U.S. labor market is sizable: the number of foreign-born doctorates who intend to stay in the United States after graduation rose from 2 thousand in 1968 to over 7 thousand by the late 1990 s. This supply shock increased the immigrant share in the flow of doctorates to the U.S. labor market from about 15 percent in the early 1970s to around 30 percent in the late 1990 s.

One potential problem with the calculation of the immigrant supply shock using the "intend to stay" information in the SED is that intentions to remain in the United States do not necessarily coincide with the actual ability to stay in the country. There is, after all, the relatively non-trivial matter of obtaining some type of work permit or permanent visa after graduation. As I will show momentarily, however, the available information indicates that the immigrant share calculated in equation (2) tracks the actual immigrant share of doctorates in the U.S. labor market very closely.

Because the SDR provides a sample of the foreign-born doctorates who actually stayed in the United States, I can use these data to validate the "intend to stay" question in the SED. In particular, I used the SDR data to calculate the immigrant share for each year-of-graduation cohort. This trend is illustrated as the broken line in the bottom panel of Figure 1. It is clear that the immigrant share calculated from the SDR almost perfectly tracks the immigrant share calculated from the SED sample of intended stayers until about 1992. In other words, throughout much of the sample period, the actual immigrant share observed in the U.S. labor market is almost identical to the immigrant share that would be predicted from the SED based on the "intend-to-stay" question that is asked of all foreign-born doctoral recipients at the time they 
receive their degrees. Beginning in 1992, however, the two data series begin to diverge. The SDR went through a major redesign in the early 1990s, and part of the divergence may be due to this redesign (or perhaps to incorrectly defined sampling weights for the subsample of foreignborn doctorates).

In fact, Figure 1 suggests that the SDR prediction of the immigrant share in the post-1992 period is contaminated by measurement error. In particular, the immigrant share calculated in the SDR in the late 1990s is actually higher than the immigrant share calculated in the SED that includes all foreign-born doctorates, regardless of whether they intend to stay or not. ${ }^{13}$ The sampling error - and the divergence of the SDR-calculated immigrant share from the "true" immigrant share - is even larger when I calculate the immigrant share for each year-ofgraduation cohort by field. As a result, I will use the SED counts of doctorates to measure the immigrant supply shock throughout the paper.

Figure 2 continues the analysis by calculating the immigrant share in the SED by cohort and field for the largest five fields of doctorates. It is evident that the nature of the immigrant supply shock differs substantially across fields, not only in terms of the size of the shock but also in terms of the timing. Consider, for example, the supply shock in electrical engineering. The immigrant share in this field rose rapidly in the 1970s, from about 19 percent in 1970 to about 40 percent in 1985, and then remained stable at that level through 1998, when it began to rise again. In contrast, the immigrant share in biological sciences actually declined throughout the 1970s, from 10.6 percent in 1970 to 7.8 percent in 1982, rose rapidly until 1996 to 31.4 percent, and

\footnotetext{
13 This anomaly could also be explained by the unlikely possibility that a large (and growing) share of native doctorates choose to migrate abroad after receiving their degrees.
} 
then began to decline again. Finally, the immigrant share in psychology has hovered between 3 and 5 percent throughout the entire sample period.

I exploit these differences in the size and timing of the immigrant supply shock to estimate the impact of immigration on the earnings of native-born doctorates. The paper focuses on 22 distinct doctoral fields that can be identified in both data sets. Table 2 reports summary statistics on degrees granted, salaries, and the trend in the immigrant share for each of these fields. There is a great deal of dispersion not only in the immigrant share and the timing of the immigrant supply shock, but also in the average salary in the various fields. In economics, for instance, the average annual salary during the 1990s was $\$ 91.6$ thousand; in the biological sciences it was $\$ 74.4$ thousand, and in chemistry it was $\$ 83.1$ thousand.

Finally, it is worth noting that a study of the impact of immigration on the earnings of doctorates based on the SED and SDR data could potentially miss an important part of the story. Both the SED and the SDR sample only those persons who received their doctorates in U.S. institutions, and the vast majority of these persons entered the country through the foreign student program. There may also be a sizable number of foreign-born persons in the U.S. labor market who received their doctorates abroad and who migrated to the United States after their education was completed. The immigrant supply shock calculated in this paper would then understate the size of the relevant migration flow.

I suspect, however, that the size of the population of science-and-engineering doctorates who received their degrees abroad and then migrated to the United States is relatively small. The 1999 wave of the SDR reported there are 114.6 thousand foreign-born doctorates in the sciences and engineering employed in the United States. The 2001 wave enumerated 123.3 thousand such persons. 
The 2000 Census specifically indicates if the person has a doctoral degree. I used the 5 percent sample of the 2000 Census to count how many foreign-born doctorates were enumerated and are employed in the mathematical sciences, other sciences, or social sciences. ${ }^{14}$ The 2000 Census enumerated a total of 133.1 thousand such doctorates. In short, almost 90 percent of all foreign-born doctorates employed in the United States in 2000 received their degrees in the United States, are enumerated in the SED, and are sampled by the SDR. ${ }^{15}$ The joint study of the SED and SDR surveys that is the foundation of the empirical analysis reported in this paper, therefore, should provide a comprehensive account of how immigration in high-skill labor markets - primarily through the foreign student program — affects economic opportunities for high-skill workers.

\section{Regression Analysis}

As noted above, the SDR gives a panel of recipients of doctoral degrees in sciences and engineering. The empirical analysis reported in this paper uses all five waves of the SDR. Let $w_{i f c}(t)$ denote the annual earnings of worker $i$, who has a doctorate in field $f$, received his doctoral degree in year $c$, and is observed at time $t$. Most studies of the labor market impact of immigration typically estimate regressions that relate the worker's earnings to some measure of immigrant penetration in the relevant labor market. Consider the following generic model:

14 The relevant occupation codes in the 2000 Census range from 100 through 196.

15 Of course, the estimate of the undercount is imprecise because it depends on the worker's reported occupation in the 2000 Census, rather than on the field of doctoral degree. Some science-and-engineering doctorates may be employed outside these fields; and some persons with other types of degrees may be employed in scienceand-engineering jobs. 


$$
\log w_{i f c}(t)=\theta p_{f c}+x_{i f c}(t)+d_{f}+y_{c}+\pi_{t}+\left(d_{f} \times \pi_{t}\right)+\varepsilon_{i f c}(t),
$$

where $x_{i f c}(t)$ is a vector indicating the number of years that the worker has been in the labor market; $d_{f}$ is a vector of fixed effects indicating the worker's field of doctoral study; $y_{c}$ is a vector of fixed effects indicating the worker's year-of-graduation cohort; $\pi_{t}$ gives a vector of period fixed effects indicating the calendar year in which the worker's earnings are observed. The worker's experience is defined as the number of years elapsed between the time the worker is observed in a particular SDR wave and the time the worker received the doctoral degree. The vector $x_{i f c}(t)$ then contains as many fixed effects as there are values for the experience variable (i.e., a dummy variable indicating if the worker has 1 year of experience, 2 years, and so on).

The linear terms of the fixed effects included in equation (3) adjust for differences in earnings across different doctoral fields, experience cells, and over time. The regression model also includes a set of interactions between the field and period fixed effects. These interactions account for the possibility that the economic returns to particular fields has been changing over time. Note that the regression cannot contain additional vectors of interactions among the various fixed effects because they would be either perfectly collinear with the variables already included in the regression or they would make it impossible to identify the parameter $\theta$. For instance, interactions between the cohort fixed effects and the period fixed effects would be perfectly collinear with the $x_{i f c}(t)$. Similarly, the inclusion of an additional vector of interactions between the worker's experience and the field fixed effects would make it impossible to identify the parameter $\theta$.

The application of ordinary least squares to the regression model in equation (3) leads to incorrect standard errors for two distinct reasons. First, the same worker can be observed up to 
five times during the duration of the SDR panel, so that the estimation technique must adjust for within-worker correlation in the error term. Second, the immigrant share for a particular cohortfield combination is constant within the subset of workers who graduated at the same time with a doctoral degree in the same field.

I use a two-stage estimation approach to adjust the standard errors both for the correlations in errors across the observations belonging to a particular individual and for the impact of the clustering of the key independent variable along the cohort-field dimension. In the first stage, I stack all workers across all panels and estimate the fixed effect for worker $i$ in field $f$ and cohort $c$. In particular, consider the regression model:

$$
\log w_{i f c}(t)=v_{i f c}+x_{i f c}(t)+\pi_{t}+\left(d_{f} \times \pi_{t}\right)+\varepsilon_{i f c}(t),
$$

where $v_{i f c}$ is the fixed effect that measures the individual's earnings potential after controlling for the worker's experience, for any period-specific labor market effects on earnings, and for the possibility that there are secular trends in the wages paid in different doctoral fields. This regression yields an estimate of the person fixed effect, or $\hat{v}_{i c}$.

In the second stage, I aggregate the estimated individual fixed effects within each fieldcohort group - that is, within each $(f, c)$ cell. Let $\hat{v}_{f c}$ be the mean value of the individual fixed effects within each of these groups. The second-stage regression model is then given by:

$$
\hat{v}_{f c}=\theta p_{f c}+d_{f}+y_{c}+\omega_{f c} .
$$


Note that the second-stage regression has one observation per field-cohort cell. I use the total of the sampling weights assigned to each person in the SDR (i.e., added across all the waves that a particular person appears in the survey) to calculate the average $\hat{v}_{f c}$. The standard errors of the second-stage regression are adjusted using a standard Huber-White correction to account for the heteroscedasticity introduced by the sampling error in the dependent variable. ${ }^{16}$

I use two alternative measures of a worker's earnings as the dependent variable in the regression analysis. The first gives the adjusted annual salary as constructed by the NSF from information on a worker's income per pay period. The second is the total annual (earned) income of the worker in the calendar year prior to the survey. Although the total annual income would seem to be a preferable measure of earnings, it is not available for the 1993 survey (cutting down the size of the first-stage regression by approximately 20 percent). ${ }^{17}$

As suggested by Welch's (1979) study of the impact of cohort size on the earnings of baby boomers, workers who received their doctoral degree in the same field at roughly the same time are more likely to influence each other's labor market opportunities than workers who are in the same field but graduated at very different times. I initially capture the (within field) similarity across workers who share the same years of experience by aggregating the flow data from the SED into three-year cohort intervals, indicating if the worker earned his doctorate between 1968 and 1970, 1971 and 1973, 1974 and 1976, and so on. There are a total of 11 three-year cohorts in

16 All second-stage regressions reported in this paper also include a variable indicating the fraction of the $(f, c)$ cell that is male. This variable is typically not very important and its exclusion would not alter the quantitative nature of the results in any appreciable way.

17 The first stage regression has 105,921 observations when the dependent variable is the log of adjusted annual salary and 84,036 observations when it is the log of annual income. 
the data (for each field). I then calculated the immigrant share for each of these cohorts and this is the key independent variable $p_{f c}$ in the second-stage regression model.

The first two rows of Table 3 report the estimates of the coefficient $\theta$. The first row uses the immigrant share defined by (1); in other words, it uses all foreign-born persons who received a doctoral degree in a particular field and year. The second row estimates the regression models using the immigrant share defined by equation (2), using only those immigrants who intend to stay in the United States. Column (1) of the table reports the coefficient of the simplest specification, a regression model that does not include the $\left(d_{f} \times \pi_{t}\right)$ interactions. Column (2) includes the interactions and column (3) adds a vector of fixed effects indicating the worker's state of residence. Regardless of the specification of the regression model, the definition of the immigrant supply shock, and the dependent variable chosen for the model, the evidence consistently reveals a numerically and statistically significant negative relation between the average earnings of doctorates in a particular field-cohort cell and the immigrant supply shock as measured by the immigrant share. Because the measure of the immigrant share that includes only the intended stayers is a conceptually better indicator of the supply shock actually affecting the U.S. labor market, the remainder of this paper exclusively uses the supply variable that includes only the foreign-born intended stayers.

In the most general specification of the regression model (columns 3 in row 2), the coefficient of the supply shock variable is -.496 (with a standard error of .166) in the adjusted salary equation and -.623 (.187) in the annual income equation. It is easier to interpret these coefficients by converting them to an elasticity that gives the percent change in earnings associated with a percent change in labor supply. Let $m_{f c}=M_{f c} / N_{f c}$, or the percentage increase in 
the labor supply of group $(f, c)$ attributable to immigration. The implied factor price elasticity is then given by:

$$
\frac{\partial \log w_{f c}}{\partial m_{f c}}=\theta\left(1-p_{f c}\right)^{2} .
$$

By 2000, immigration had increased the immigrant share in the stock of doctorates in the United States to 23.6 percent. Equation (6) then implies that the factor price elasticity—evaluated at the mean value of the supply increase — can be obtained by multiplying $\theta$ by approximately 0.6 . The implied elasticity in the adjusted salary regression is then -0.30 (or $-0.496 \times 0.6$ ), while the implied elasticity in the annual income regression is -.37 . Put differently, a 10 percent supply shock (i.e., an immigrant flow that increases the number of doctorates in a particular field-cohort group by 10 percent) reduces annual earnings by about 3 to 4 percent. ${ }^{18}$

As noted above, I aggregated the supply measures into three-year cohorts to capture the notion that workers who share the same field and graduate at roughly the same time are perfect substitutes. An alternative approach, introduced by Welch (1979), uses some type of moving average of the supply shock. In other words, the type of supply shock encountered by a native worker who received a doctoral degree in 1980 will be affected by the supply shock that occurred around 1980. The operational difficulty, of course, is the choice of the subset of years over which workers in a particular field are relatively substitutable. Suppose that workers in $k$

\footnotetext{
18 The results that would be obtained by using the immigrant share that can be calculated from within the SDR are qualitatively similar, but not as large. For instance, the coefficient that would be analogous to that reported in the last column of row 2 in Table 3 is -.281 (.131), implying a factor price elasticity of -.17 . The smaller size of the coefficient is consistent with the conjecture that the SDR-implied immigrant share for specific field-cohort cells contains more measurement error than the comparable statistic in the SED.
} 
adjacent cells around degree-granting date $c$ are similar (with $k$ odd). The relevant supply shock facing a worker in cell $(f, c)$ is then given by:

$$
\bar{p}_{f c}=\frac{\sum_{\ell=-(k-1) / 2}^{\ell=(k-1) / 2} M_{f, c+\ell}}{\sum_{\ell=-(k-1) / 2}^{\ell=(k-1) / 2}\left(M_{f, c+\ell}+N_{f, c+\ell}\right)},
$$

so that the immigrant supply shock is approximately given by a $k$-year moving average of the immigrant share series. I used equation (7) to calculate a five-year moving average of the supply shock for each doctoral field. ${ }^{19}$ Note that there are now more observations in the second-stage regressions since each year-of-graduation cohort provides "independent" information about the immigrant supply shock to the regression model.

Rows 3 and 4 of Table 3 report the regression coefficients obtained by using the five-year moving average measure of the immigrant share. The coefficients are very similar to those obtained when using the 3 -year grouping. For example, the coefficient $\theta$ in the annual income equation is -.554 (with a standard error of .123), implying a factor price elasticity of - .33 .

In sum, the coefficients reported in Table 3 indicate that the immigration of doctorates (mainly through the foreign student program) had a sizable adverse impact on the earnings of competing native workers. Moreover, as Table 4 shows, the results are roughly similar even when the regression model is subjected to a variety of major specification changes. For simplicity, the coefficients reported in Table 4 are calculated from the most general specification

\footnotetext{
19 The moving average is calculated over all available data, even at the truncated endpoints of the time series of year-of-graduation cohorts. As a result, there are no missing values for the immigrant share defined by equation (7).
} 
of the regression model (which includes the field-period interactions and the state of residence fixed effects).

Rows 2 and 3 of Table 4 re-estimate the regression models in the samples of male and female native doctorates, respectively. The estimated coefficients are negative and significant for both groups, with the point estimate of the effect being slightly larger for women. The next two rows report the regression coefficients by type of employer: academic or non-academic. The two coefficients hover around -.5 in the annual income equations, implying that the adverse impact of an immigrant supply shock on one segment of the market completely spills over into the other segment. Finally, the last three rows of the table report the coefficients when the model is estimated separately in the sets of cohorts that received their degrees in the 1970s, the 1980s, or the 1990s, respectively. Although there is a lot of dispersion in the estimated coefficients, the coefficients are always negative and often significant. In sum, the evidence suggests a remarkable consistency in the negative relation between the earnings of native-born doctorates who received their degrees in the same field at roughly the same time and the immigrant supply shock affecting that specific group.

\section{Estimating a Marginal Productivity Model}

Although the studies in the immigration literature often estimate the generic regression model giving the relation between the wage of a particular worker (or group of workers) and the immigrant share, there is an alternative approach, more closely linked with economic theory, that can be used to directly estimate the relevant factor price elasticity. Consider the following specification of a marginal productivity equation: 


$$
\hat{v}_{f c}=\eta \log L_{f c}+d_{f}+y_{c}+\xi_{f c} .
$$

where $L_{f c}$ gives the total number of doctorates in field $f$ and cohort $c$; and $\xi_{f c}$ is the error term. The parameter $\eta$ gives the factor price elasticity, the percent change in the wage associated with a one-percent increase in labor supply.

Ordinary least squares estimation of equation (8) would obviously lead to biased estimates of $\eta$ because the supply of workers to the various cohort-field groups is likely to be endogenous over the 33-year period spanned by the data. The economic question at the core of this paper, however, suggests an instrument for the size of the workforce in each field-cohort group: the number of immigrants in the $(f, c)$ cell. In other words, the influx of foreign students into particular doctoral fields at particular times provides the supply shifter required to identify the labor demand function. This instrument would be valid if the foreign student influx into particular doctoral fields were independent of the relative wages offered in the various fields. Since most foreign students intend to remain in the United States, however, the number of immigrants in a field will likely respond to shifts in the wage structure. Income-maximizing behavior on the part of potential foreign students would generate larger flows into those fields that have relatively high wages. This behavioral response would build in a positive correlation between the size of the workforce in a particular cohort-field cell and wages. The IV regression coefficients would then understate the adverse wage impact of a relative supply increase. 
I estimate the marginal productivity model in (8) by using the mean fixed effects computed from the first stage regression in equation (4), with $\log M_{f c}$ as the instrument. ${ }^{20}$ The top two rows of Table 5 report the regression coefficients estimated in the sample of native doctoral recipients. The values of the factor price elasticities reported in these two rows are almost identical to those calculated earlier using the immigrant share specification in equation (3). For example, the factor price elasticities reported in Table 5 for the annual income equations are $-.31(.14)$ and $-.34(.09)$, depending on whether I use the 3-year cohort groups or the 5-year moving average. The implied elasticities reported earlier when I used the immigrant share as the independent variable were -.30 and -.36 , respectively. In short, the evidence strongly suggests that an immigration-induced 10 percent increase in the supply of a narrowly defined high-skill group lowers the wage of that group by between 3 and 4 percent. It is worth noting that these factor price elasticities are slightly higher than those estimated by Freeman $(1975,1976)$ in his series of cobweb-based studies of high-skill science labor markets. For example, Freeman's estimates of the factor price elasticity in engineering, based on (non-immigrant induced) supply shocks in the 1950s and 1960s, lie between -.1 and -.2.21

20 The $R$-squared of the first-stage regression in the IV regression model corresponding to columns 3 of Table 5 is .976 when the regression uses the 3-year cohort groupings and .978 when the regression uses the 5-year moving average. The coefficient of $\log M$ in these regressions is $.452(.079)$ and $.455(.045)$, respectively.

${ }^{21}$ I also estimated the IV regressions by doctoral field. These within-field regressions obviously cannot include cohort fixed effects or interactions between work experience and survey year, so that the measured impact of an immigration-induced supply increase is contaminated by important omitted factors (e.g., increases in immigration may be correlated with improvements in labor market conditions for a particular field). There is a great deal of interfield dispersion in the estimated coefficients, but the estimated elasticities tend to be negative. The estimated factor price elasticities using adjusted annual salary as the dependent variable and the 3-year cohort groupings are: -.140 (.035) in computer science; $-.388(.322)$ in mathematics; $-1.570(1.280)$ in agricultural sciences; $-.565(.204)$ in biology, $-.054(.081)$ in environmental science; $-.119(.049)$ in health sciences; $-.250(.205)$ in chemistry; -.892 (.388) in earth sciences; -.629 (.543) in physics; -.003 (.278) in other physical sciences; 3.503 (1.357) in economics; -.291 (.392) in political science; -1.080 (1.550) in sociology; $-1.475(.688)$ in other social sciences; .586 (.411) in psychology; -1.444 (1.328) in aerospace engineering; $-1.436(2.132)$ in chemical engineering; -.642 (.264) in civil engineering; -.104 (.273) in electrical engineering; -.901 (.588) in industrial engineering; $-.240(.129)$ in mechanical engineering; and $-.236(.485)$ in other engineering. 
It is important to investigate if the adverse wage impact of the immigrant supply shock also applies to the immigrants themselves. There is, in fact, very little difference between the average earnings of native- and foreign-born doctorates in the United States. In 2001, the average annual income of the typical native-born doctorate was $\$ 90.5$ thousand, while that of the typical foreign-born doctorate was $\$ 88.5$ thousand. The adjusted log wage gap between immigrant and native doctorates - after controlling for the worker's gender, a vector of field fixed effects, and a vector of year-of-graduation fixed effects - was $+.013(.010)$, a wage gap that is both numerically and statistically trivial.

The middle panel of Table 5 re-estimates the marginal productivity model using the sample of foreign-born doctorates to examine if the immigrant supply shock also affects their earnings opportunities. More precisely, I run the first-stage earnings function using only the sample of foreign-born doctorates, obtain the mean $\hat{v}_{f c}$ for each $(f, c)$ cell, and estimate the labor demand function in (8). Although the factor price elasticities estimated in the sample of immigrants tend to be slightly more negative than those estimated in the sample of native-born doctorates, the difference between the two sets of estimates is not statistically significant. ${ }^{22}$ The similarity between the two sets of elasticities is not surprising because the two groups have almost identical incomes (within field-cohort cells). Therefore, it seems that foreign and native doctorates who belong to the same field-cohort cell are close to being perfect substitutes.

The bottom panel of Table 5 uses this insight and estimates the labor demand function using the sample of all doctorates, regardless of whether they are native-born or foreign-born. Not surprisingly, the factor price elasticity for annual income lies between -.3 and -.4, indicating 
that immigration into a particular field-cohort group adversely affects all workers in that group

by a numerically important amount. ${ }^{23}$

\section{Postdoctoral Appointments}

In the 1980 s and 1990 s it became relatively common for many newly minted doctorates in some fields to work in "postdoctoral appointments" for a number of years after graduation. ${ }^{24}$ These postdoc positions tend to offer relatively low wages when compared to the salary that would be offered, for instance, in a tenure-track academic job. In fact, the postdoc appointments are low-pay even when compared to the salary opportunities offered to new college graduates with little labor market experience.

The various waves of the SDR report if the respondent is working at a postdoctoral appointment during the survey week. ${ }^{25}$ Table 6 summarizes the data on the propensity of native

22 For example, in the most general specification of the annual income regression, the elasticities are -.306 (.141) and $-.432(.235)$ in the sample of native and foreign doctorates, respectively. The $t$-ratio testing for the difference between these two statistics is 0.46 .

23 It would be of interest to determine if the adverse wage impact of the foreign student influx depends on the quality of the universities attended by the native-born doctorates. Unfortunately, the SDR does not identify the degree-granting institution, so that it is not possible to link the data with detailed information on institutional quality. The only quality-related variable available in the SDR is the Carnegie classification. However, due to confidentiality considerations, the Carnegie ranking is not reported for many of the persons who received their degree after 1992. Moreover, even in the sample of doctorates who graduated prior to 1991, the Carnegie classification is not a very discriminating measure of school quality: 70.8 percent of native-born and 69.1 percent of foreign-born doctorates received their degree from the top tier in the Carnegie ranking (Research University I).

${ }^{24}$ Freeman et al (2001) report that the career path for the typical doctorate in bioscience changed in the 1980 s so that it is not uncommon for newly minted doctorates to go through a series of postdocs before they start their first "real job" sometime in the mid-30s. A National Academy of Sciences (2000) report on postdoctoral appointments summarizes many of the key issues and reports some of the relevant data.

25 The postdoctoral information provided by the 1995 wave differs slightly from that of the other waves. The information on postdoctoral appointments is typically obtained from questions relating to the respondent's current job. In 1995, however, the information refers to the respondent's "principal" job. All waves are included in the empirical analysis reported below. The results are only slightly different if the 1995 wave is excluded from the analysis. 
doctorates to be employed as postdocs, as well as the average salary of workers employed in such jobs. To more clearly show the importance of postdoctoral appointments in some doctoral career tracks, the table focuses on the sample of doctorates under the age of 40 .

The data indicate that postdoctoral appointments are very common in some fields. ${ }^{26}$ The proportion of young workers in postdoctoral positions is 28.7 percent in the biological sciences, 17.4 percent in physics, and 9.3 percent in chemistry. In contrast, postdoctoral appointments are relatively rare in economics and computer sciences, where only 1 to 3 percent of the doctorates hold such jobs. The last two columns of the table show that postdoctoral appointments typically pay a great deal less than regular jobs. On average, a doctorate under the age of 40 working in a postdoctoral appointment earns $\$ 36.0$ thousand as compared to $\$ 65.9$ thousand for a doctorate working in a regular appointment. This wage gap is equally large within fields: postdocs in biology, for example, earn $\$ 34.2$ thousand as compared to $\$ 64.0$ thousand for biologists with regular appointments. It is insightful to contrast these salaries with the annual earnings reported by college graduates in the 2000 Census. Male workers who have only a college diploma, work full time, and are between 25 and 29 years old earned $\$ 33.0$ thousand, while those who were 3034 years old earned $\$ 42.3$ thousand. In sum, the salary opportunities provided by postdoctoral appointments fall far short of what even younger persons with less education could earn in the U.S. labor market.

The prevalence (and growth) of low-pay postdoctoral appointments as part of the career path in some doctoral fields suggests that one possible channel through which immigration affects the wage structure is by increasing the probability that newly minted doctorates must first 
serve an "internship" in a series of postdoctoral appointments. Put differently, the sizable immigration-induced increase in the supply of doctorates in some fields and for some cohorts may soften labor market conditions sufficiently that scientific labs, for example, can attract many newly minted doctorates to work in low-pay postdoctoral positions for a relatively long period of time. ${ }^{27}$

I used a variation of the marginal productivity model presented earlier to determine if the immigrant supply shock indeed increases the probability that native doctorates end up in postdoctoral positions. In particular, I estimated the regression model summarized by equations (4) and (8) using the probability that a particular worker in field $f$ and cohort $c$ is employed in a postdoctoral appointment at time $t$ as the dependent variable. Note that by including interactions between the field and period fixed effects, the regression model controls for the possibility that the demand for postdocs is driven partly by such factors as increased NIH funding by field; such funding is typically the financial constraint faced by Principal Investigators in university labs before they can staff postdoctoral positions.

Table 7 summarizes the relevant IV coefficients from the second-stage regression. Using the three-year cohort grouping, the elasticity estimated in the sample of native doctorates is .406 (.153). An immigration-induced 10 percent increase in supply, therefore, raises the probability of

\footnotetext{
26 The percent of workers employed as postdocs and the average salaries reported in Table 6 are obtained by pooling all persons across all the available waves of the SDR between 1993 and 2001 and treating each personyear observation as an independent observation.

27 Of course, the increasing prevalence of postdoctoral appointments in some fields may also reflect structural changes in the training process - for example, it may now take longer to acquire the skills expected of doctorates in some sciences and postdocs arise as a way of filling the need for the longer apprenticeship period. The empirical analysis reported below, however, shows that there is a strong correlation between the prevalence of postdoctoral appointments and the size of the immigrant influx in a particular field-cohort cell. It seems unlikely that the increase in the frequency of postdoctoral appointments mandated by educational needs would be so strongly correlated with the field-cohort variation in the number of foreign students.
} 
being employed in a postdoctoral appointment by about 4.0 percent. The response is even larger when the model is estimated in the sample of younger native workers: A 10 percent immigrationinduced increase in supply increases the probability of postdoctoral employment by about 21.6 percentage points.

The bottom two panels of Table 7 re-estimate the postdoctoral propensity model in the sample of foreign-born doctorates (panel B) and in the pooled sample of doctorates (panel C). The estimated elasticities are roughly similar across the various samples. Among younger workers, for example, a 10 percent immigration-induced increase in supply increases the probability of being employed in a postdoctoral appointment by 20 to 30 percent, regardless of whether the affected doctorates are native-born or foreign-born.

Finally, because postdocs earn about 50 percent less than comparable workers in "regular" jobs, the results in Table 7 suggest that an important part of the wage impact of immigration may be taking place through the "crowding" of workers in immigrant-penetrated fields into postdoctoral appointments. To measure the extent to which postdoctoral appointments provide a channel for the labor market to reduce the wages of the affected workers, I reestimated the labor demand model in the sample of workers who are not employed in postdoctoral appointments. If the sole impact of immigration on labor market opportunities for doctorates was through the increased placing of workers in low-pay postdoctoral appointments, this regression specification should generate zero factor price elasticities.

In fact, as Table 8 shows, the estimated elasticities are still negative, but only about half the size of the elasticities reported earlier in the paper (see the analogous Table 5). For example, the factor price elasticity estimated in the sample of native workers using the 3-year cohort group is $-.306(.141)$ when using all native workers, and -.125 (.084) when using the sample of native 
doctorates not employed as postdocs. It seems, therefore, that roughly half of the adverse wage impact of immigration on high-skill labor markets can be attributed directly to the increased use of low-pay postdoctoral appointments as a way of adjusting to the increase in supply.

\section{Simulating the Wage Effects of the Foreign Student Program}

I now use the factor price elasticity estimated in this paper to simulate the wage impact of the foreign student influx that entered the United States between 1993 and 2001. Assuming that capital is constant and ignoring spillover effects across fields, the total impact of immigration on the $\log$ wage of native workers in field $f$ is: ${ }^{28}$

$$
\Delta \log w_{f}=\eta m_{f}
$$

where $m_{f}$ gives the percentage change in labor supply due to immigration in field $f$. I define $m_{f}$ as:

$$
m_{f}=\frac{\Delta \tilde{M}_{f, 1993-2001}}{\left(\tilde{N}_{f, 2001}+\tilde{M}_{f, 2001}\right)-\Delta \tilde{M}_{f, 1993-2001}},
$$

where $\Delta \tilde{M}_{f, 1993-2001}$ gives the change in the stock of foreign-born doctorates in field $f$ between 1993 and 2001 and is calculated from the SED as the total number of doctorates awarded in field $f$ to foreign-born persons (who intend to stay in the United States) during that period; and $\tilde{N}_{f, 2001}$

\footnotetext{
28 The assumption of a constant capital stock implies that the resulting wage consequences should be interpreted as short-run impacts. Over time, the changes in factor prices will fuel adjustments in the capital stock
} 
and $\tilde{M}_{f, 2001}$ give the stock of native and foreign-born doctorates in field $f$ as of 2001 and are estimated from the 2001 wave of the SDR. The definition of the supply shock in (10) treats all foreign-born persons who obtained their degree prior to 1993 as part of the native baseline. In effect, the predicted wage effect (multiplied by minus one) gives the additional log wage that native doctorates in 2001 would have earned had the foreign student program been halted in 1993.

The simulation uses the log adjusted annual salary as the dependent variable because this measure of earnings is available in both 1993 and 2001. Table 9 summarizes the results of the simulation using the -0.260 estimate of the factor price first reported in Table 5 . On average, the 1993-2001 influx increased the supply of doctorates by 13.9 percent. This supply shock reduced the wage of the average worker with a doctorate in science and engineering by approximately 3.6 percent. The predicted losses are sometimes very large because the supply shock in particular fields has been substantial. In computer science and mechanical engineering, for example, immigration increased the supply of doctorates by over 36 percent. This supply shock resulted in predicted wage losses of nearly 10 percent.

The last column of the table reports what actually happened to the log adjusted annual salary between 1993 and 2001. The typical doctorate experienced a 5.2 percent increase in real wages. The foreign student influx, therefore, reduced wage growth by about 40 percent of what it would have been in its absence. Note, however, that there is a great deal of dispersion across fields in the relative impact of foreign students. In earth sciences, for example, the foreign student influx "explains" most of the 3.8 percent drop in real wages experienced by doctorates in 
that field. In contrast, the real wage of economists would have risen by 20 percent more had there been no immigrant influx during the period.

It is important to point out a number of conceptual problems and interpretation difficulties inherent with this type of simulation. Any simulation of the wage impact of immigration must be based on a particular set of assumptions describing how the economy adjusted to the immigrant influx. Needless to say, different counterfactuals inevitably lead to different simulated impacts.

The simulation summarized in Table 9 explicitly holds all other factors constant, so that neither native workers nor firms adjust to the increased number of foreigners who sought doctorates in American universities and then remained in the U.S. labor market. There are many ways in which such adjustments could take place, and the resulting estimates of the wage impact of immigration could be correspondingly lower or higher, depending on the assumed counterfactuals. Suppose, for example, that native students would have taken the place of the foreign students admitted to the various graduate programs if there had been an enforceable prohibition on the entry of foreign students. In this extreme case, the total supply of doctorates in particular field-cohort groups would have been the same regardless of whether foreign students had been admitted to U.S. universities. This counterfactual implies that the wage structure in the doctoral labor market today would be exactly what we now observe, despite the fact that not a single foreign student entered the country.

Alternatively, suppose that native students responded to the immigrant influx in particular fields and in particular years by moving to other departments in the university, or perhaps by going to law or business school. This spillover effect of immigration would then tend to lower wages throughout the entire high-skill sector, not just in the fields penetrated by immigrants. 
These across-field "migration flows" suggest that the labor market impact of immigration estimated in this paper is numerically smaller than the actual impact, since the movement of native students across fields would tend to arbitrage wage differences.

The simulation exercise reported in Table 9 is best seen as an attempt to calculate the short-run impact of immigration, before any adjustments take place. Neither the supply and career decisions of native students nor the level of demand for doctorates in particular fields is affected by immigration. It would be interesting, of course, to simulate the impact of immigration in the market for high-skill workers under alternative scenarios.

\section{Summary}

This paper analyzed the impact of immigration on high-skill labor markets. The analysis used data drawn from the Survey of Earned Doctorates, a population enumeration of all doctoral degrees awarded by U.S. universities, and the Survey of Doctoral Recipients, a biennial longitudinal data set that provides detailed information on labor market conditions for a sample of doctorates in science and engineering.

The empirical study is based on the intuitively appealing notion that shifts in labor supply in a finely-detailed skill group should affect the earnings and employment opportunities of that skill group. Put differently, immigration-induced shifts in the supply of students entering particular doctoral fields at particular times can be used to identify the impact of immigration on the earnings of doctorates.

The analysis indicates that increases in the number of foreign-born doctorates, primarily through the foreign student program, have a significant adverse effect on the earnings of competing workers, regardless of whether the competing workers are native-born or foreign- 
born. An immigration-induced 10 percent increase in the supply of doctorates in a particular field at a particular time reduces the earnings of that cohort of doctorates by about 3 to 4 percent. About half of this adverse wage effect can be attributed to the increased prevalence of low-pay postdoctoral appointments in fields that have softer labor market conditions because of largescale immigration.

These results have implications in a number of different policy contexts. For instance, there has been a long-standing debate about whether immigration affects labor market conditions for native workers at all. This study, along with other recent empirical work, seems to suggest that the supply-demand textbook model is correct after all: increases in labor supply do move the labor market along the demand curve and lead to lower wages for competing workers.

It is also the case that economic opportunities in high-skill labor markets are among the key determinants of the career decisions made by the native-born student population. The increase in the number of foreign doctorates has clearly reduced economic opportunities in some fields relative to others, and may be an important factor driving native students to enter particular occupations and avoid others.

For example, the wage that could be earned by native postdoctoral workers employed in research biology labs is much lower than it would have been in the absence of the immigrant influx, perhaps motivating bright U.S.-born undergraduates to pursue professional occupations that have not been targeted by immigration. The low wage paid to postdoctoral workers in these biology labs, however, still offers a very attractive opportunity when contrasted to the compensation available in other countries, so that the incentives for even more foreign students to enter the United States are not greatly reduced. In a sense, there is a potential "vicious cycle" where the incentives of research labs to offer low wages to their workers barely affect the supply 
of foreign doctorates, but have a substantial impact on the career decisions of native workers. In the resulting equilibrium, research labs find that they must keep recruiting from abroad because "natives do not want to do the type of work that immigrants do." Although we do not yet know the magnitude of the supply elasticities that determine inter-field migration flows, the wage effects of large-scale immigration into some doctoral fields are very large and would be expected to be a crucial factor in labor supply decisions.

Finally, although the foreign student program grew rapidly in the past three decades, this growth occurred without any systematic study of the costs and benefits that such a program entails for the native-born population. This paper addressed an important component in such a cost-benefit analysis - the cost borne by doctorates in the U.S. labor market. There is an equally important component that has not yet been analyzed carefully, namely the benefits of the program, such as the possibility that the sizable increase in the skill endowment of the workforce accelerates the rate of scientific discovery. These benefits could be very large and accrue to particular parts of the population, so that high-skill immigration may have significant efficiency and distributional effects that have yet to be analyzed. 


\section{References}

Altonji, Joseph G. and Card, David. "The Effects of Immigration on the Labor Market Outcomes of Less-Skilled Natives," in John M. Abowd and Richard B. Freeman, eds., Immigration, Trade, and the Labor Market. Chicago: University of Chicago Press, 1991, pp. 201-234.

Borjas, George J. "The Economic Analysis of Immigration," in Orley C. Ashenfelter and David Card, eds., Handbook of Labor Economics, Vol. 3A. Amsterdam: Elsevier, 1999, pp. 1697-1760.

Borjas, George J. "The Labor Demand Curve Is Downward Sloping: Reexamining the Impact of Immigration on the Labor Market," Quarterly Journal of Economics (November 2003): 1335-1374.

Borjas, George J., Richard B. Freeman, and Lawrence F. Katz. "How Much Do Immigration and Trade Affect Labor Market Outcomes?," Brookings Papers on Economic Activity (1997): 1-67.

Card, David. "The Impact of the Mariel Boatlift on the Miami Labor Market," Industrial and Labor Relations Review 43 (January 1990): 245-257.

Card, David. "Immigrant Inflows, Native Outflows, and the Local Labor Market Impacts of Higher Immigration,” Journal of Labor Economics (January 2001): 22-64.

Card, David, and Thomas Lemieux, "Can Falling Supply Explain the Rising Return to College for Younger Men? A Cohort-Based Analysis," Quarterly Journal of Economics 116 (May 2001), 705-746.

Ehrenberg, Ronald. Tuition Rising: Why College Costs So Much. Cambridge, MA: Harvard University Press, 2000.

Finn, Michael G. "Stay Rates of Foreign Doctorate Recipients from U.S. Universities, 2001,” Oak Ridge Institute for Science and Education, Oak Ridge, Tennessee, 2003.

Freeman, Richard B. "Supply and Salary Adjustments to the Changing Science Manpower Market: Physics, 1948-1975," American Economic Review 65 (March 1975): 27-39.

Freeman, Richard B. "A Cobweb Model of the Supply and Starting Salary of New Engineers," Industrial and Labor Relations Review 29 (January 1976): 236-248.

Freeman, Richard B., Eric Weinstein, Elizabeth Marincola, Janet Rosenbaum, and Frank Solomon. "Competition and Careers in Bioscience," Science, December 14, 2001, pp. 22932294. 
Friedberg, Rachel M. "The Impact of Mass Migration on the Israeli Labor Market," Quarterly Journal of Economics 116 (November 2001): 1373-1408.

Friedberg, Rachel M. and Jennifer Hunt. "The Impact of Immigration on Host Country Wages, Employment and Growth," Journal of Economic Perspectives 9 (Spring 1995): 23-44.

Grossman, Jean Baldwin. "The Substitutability of Natives and Immigrants in Production," Review of Economics and Statistics 54 (November 1982): 596-603.

Hamermesh, Daniel. Labor Demand. Princeton: Princeton University Press, 1993.

LaLonde, Robert J. and Robert H. Topel. "Labor Market Adjustments to Increased Immigration," in John M. Abowd and Richard B. Freeman, eds., Immigration, Trade, and the Labor Market. Chicago: University of Chicago Press, 1991, pp. 167-199.

Levin, Sharon G., Grant C. Black, Anne E. Winkler, and Paula E. Stephan. "Differential Employment Patterns for Citizens and Non-Citizens in Science and Engineering in the United States: Minting and Competitive Effects," Growth and Change, forthcoming 2004.

National Academy of Sciences, Committee on Science, Engineering, and Public Policy. Enhancing the Postdoctoral Experience for Scientists and Engineers: A Guide for Postdoctoral Scholars, Advisers, Institutions, Funding Organizations, and Disciplinary Societies. Washington, DC: National Academy Press, 2000.

Samuelson, Paul A. Economics, $9^{\text {th }}$ Edition. New York: McGraw-Hill, 1973.

Schoeni, Robert F. "The Effect of Immigrants on the Employment and Wages of Native Workers: Evidence from the 1970s and 1980s," unpublished paper, The RAND Corporation, March 1997.

Smith, James P. and Barry Edmonston, editors. The New Americans: Economic, Demographic, and Fiscal Effects of Immigration. Washington, D.C.: National Academy Press, 1997. 2002 .

U.S. Department of Education. Digest of Education Statistics, 2002, Washington, DC,

Welch, Finis. "Effects of Cohort Size on Earnings: The Baby Boom Babies' Financial Bust," Journal of Political Economy 87 (October 1979, Part 2): S65-S97. 
Figure 1. Doctorates awarded, 1968-2000

\section{A. Doctorates awarded each year}

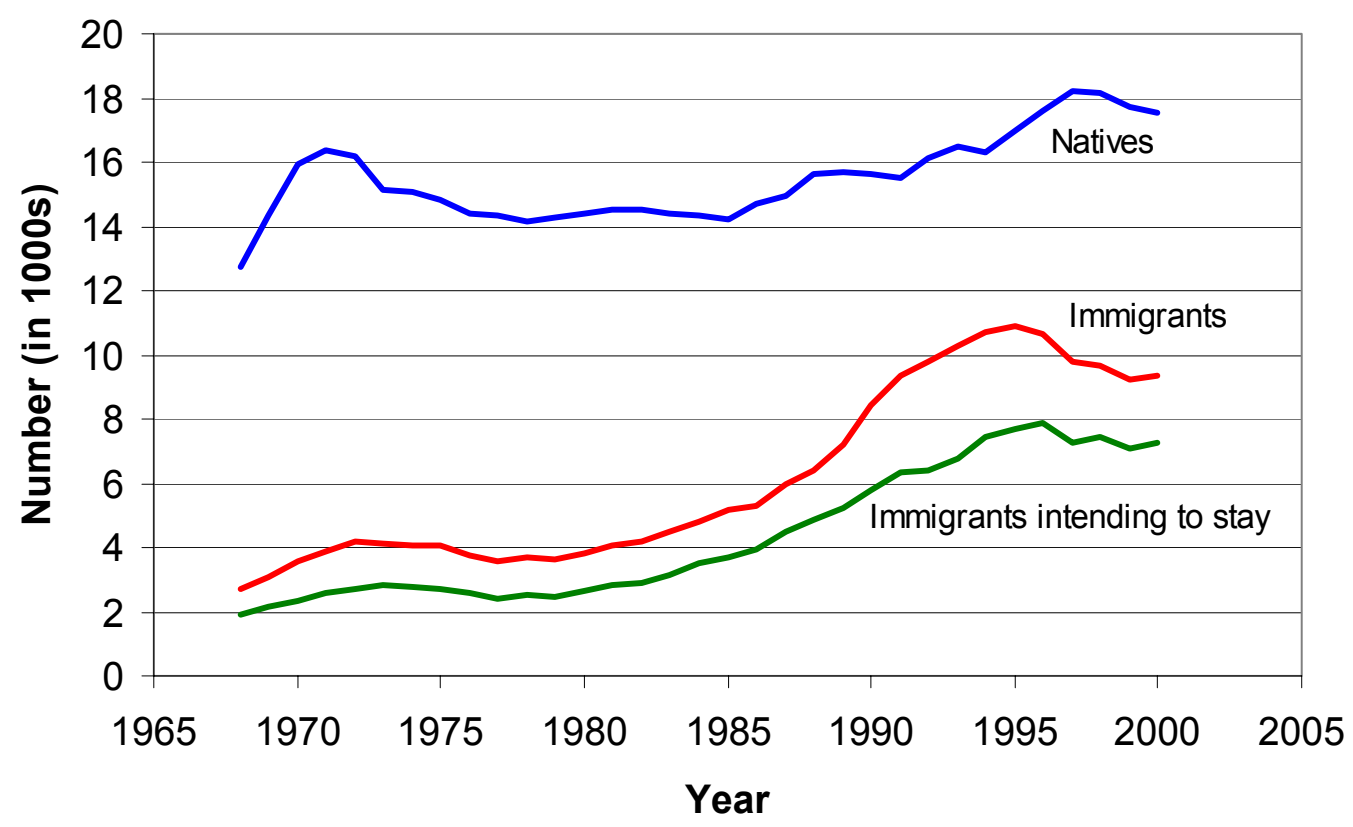

\section{B. Immigrant share}

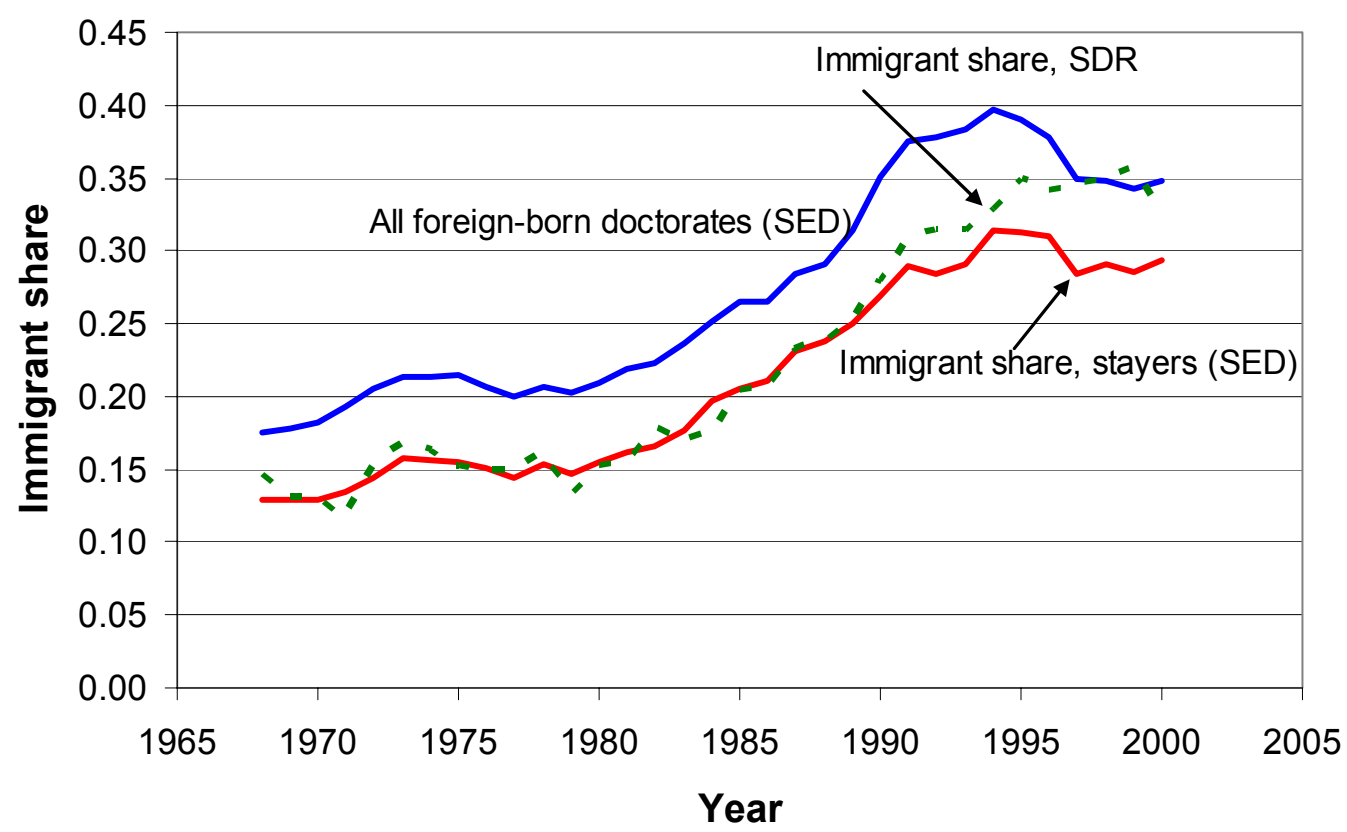

Source: The data reported in Panel A is drawn from the Survey of Earned Doctorates; the data reported in panel B is drawn from both the Survey of Earned Doctorates and the Survey of Doctoral Recipients. The "immigrant share, stayers (SED)" series in the bottom panel gives the fraction of workers who are foreign-born when the foreign-born population includes only those newly minted doctorates who intend to stay in the United States after graduation. 
Figure 2. The immigrant supply shock, selected fields

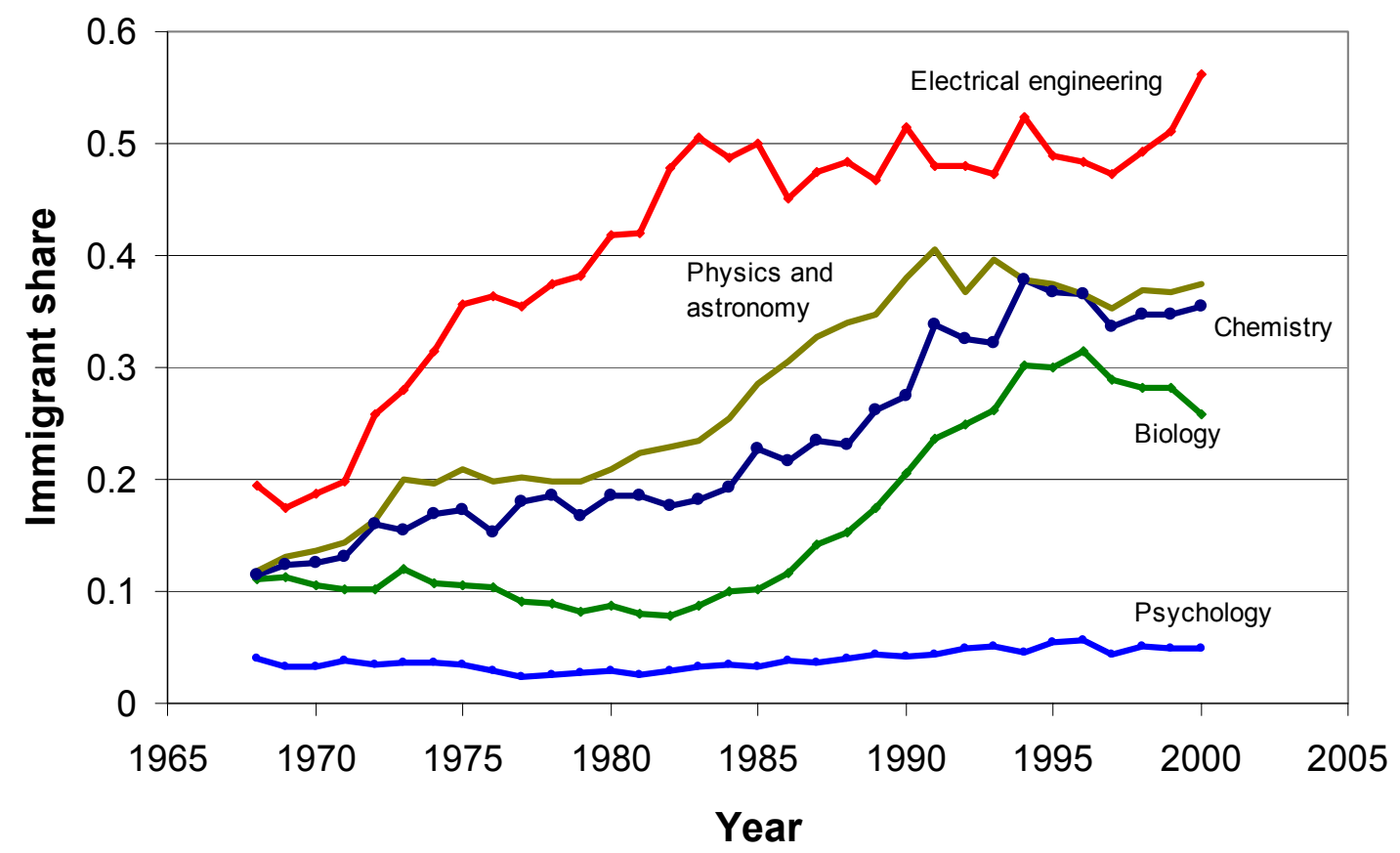

Source: Survey of Earned Doctorates. The five fields in the figure are the fields that produced the largest number of doctorates between 1968 and 2000. 
Table 1. Doctorates awarded to foreign-born persons, 1968-2000

Number of doctorates
$\begin{aligned} & \text { Percent with high school diploma from abroad } \\ & \end{aligned}$
Percent with a bachelor's diploma from abroad
Percent who expect to remain in the U.S.


Table 2. Doctorates awarded in 1968-2000, by field

Field:

Computer and information sciences

Mathematical sciences

Agricultural and food sciences

Biological sciences

Environmental life sciences

Health and related sciences

Chemistry, except biochemistry

Earth sciences, geology and oceanography

Physics and astronomy

Other physical sciences

Economics

Political science

Sociology and anthropology

Other social sciences

Psychology

Aerospace and related engineering

Chemical engineering

Civil and architectural engineering

Electrical, electronic engineering

Industrial engineering

Mechanical engineering

Other engineering

\begin{tabular}{|c|c|c|c|c|}
\hline \multirow{2}{*}{$\begin{array}{l}\text { Ph.D.s } \\
\text { granted } \\
(1,000 \mathrm{~s})\end{array}$} & \multirow{2}{*}{$\begin{array}{l}\text { Average } \\
\text { Salary } \\
(\$ 1,000) \\
\end{array}$} & \multicolumn{3}{|c|}{$\begin{array}{l}\text { Percent foreign-born } \\
\text { (includes only foreign students } \\
\text { intending to stay) }\end{array}$} \\
\hline & & $1970 \mathrm{~s}$ & $\underline{1980 \mathrm{~s}}$ & $1990 \mathrm{~s}$ \\
\hline 14.0 & 88.0 & $\overline{19.6 \%}$ & $\overline{33.9 \%}$ & $\overline{41.6 \%}$ \\
\hline 32.5 & 76.3 & 16.1 & 33.7 & 42.6 \\
\hline 34.8 & 68.9 & 20.0 & 21.6 & 34.6 \\
\hline 140.2 & 74.4 & 10.1 & 11.3 & 27.5 \\
\hline 2.8 & 70.2 & 10.2 & 10.5 & 24.2 \\
\hline 26.5 & 75.9 & 11.5 & 11.1 & 16.7 \\
\hline 64.2 & 83.1 & 15.8 & 21.1 & 34.0 \\
\hline 19.8 & 73.5 & 11.8 & 13.7 & 23.5 \\
\hline 45.1 & 82.6 & 18.0 & 28.1 & 37.5 \\
\hline 3.0 & 66.0 & 18.2 & 24.2 & 39.1 \\
\hline 28.8 & 91.6 & 17.2 & 28.7 & 36.7 \\
\hline 23.4 & 72.6 & 9.4 & 15.9 & 14.4 \\
\hline 29.8 & 61.7 & 6.8 & 9.6 & 13.0 \\
\hline 16.7 & 69.6 & 12.2 & 18.5 & 22.2 \\
\hline 100.7 & 70.1 & 3.2 & 3.4 & 4.9 \\
\hline 5.6 & 91.1 & 29.7 & 44.1 & 35.1 \\
\hline 15.7 & 93.1 & 37.1 & 40.9 & 43.6 \\
\hline 13.6 & 83.3 & 42.3 & 51.8 & 54.2 \\
\hline 35.4 & 99.7 & 30.0 & 47.0 & 49.2 \\
\hline 12.2 & 87.1 & 34.9 & 45.0 & 46.0 \\
\hline 18.3 & 86.2 & 31.0 & 50.7 & 49.1 \\
\hline 32.0 & 89.3 & 28.2 & 40.8 & 43.9 \\
\hline 715.3 & 78.2 & 19.7 & 27.5 & 33.4 \\
\hline
\end{tabular}

All fields

$715.3 \quad 78.2$

19.7

33.4

Source: Survey of Earned Doctorates (except for the average salary data, which is drawn from the Survey of Doctoral Recipients). The salary statistic gives the mean salary (in 2001 dollars) calculated over all workers in each doctoral field throughout the 1993-2001 sampling period. 


\section{Table 3. Basic estimates of wage impact of immigration (Coefficient of immigrant share)}

\begin{tabular}{|c|c|c|c|c|c|c|}
\hline \multirow[b]{2}{*}{ Measure of immigrant share: } & \multicolumn{3}{|c|}{ Adjusted annual salary } & \multicolumn{3}{|c|}{ Income earned last year } \\
\hline & (1) & (2) & (3) & $\underline{(1)}$ & $\underline{(2)}$ & $\underline{(3)}$ \\
\hline \multirow[t]{2}{*}{ 1. Three-year cohort } &.$- \overline{313}$ & -.370 & -.378 &.$- \overline{415}$ &.$- \overrightarrow{481}$ & -.487 \\
\hline & $(.141)$ & $(.155)$ & $(.155)$ & $(.163)$ & $(.175)$ & $(.176)$ \\
\hline \multirow{2}{*}{$\begin{array}{l}\text { 2. Three-year cohort, including only } \\
\text { intended stayers }\end{array}$} & -.417 & -.489 & -.496 & -.536 & -.618 & -.623 \\
\hline & $(.151)$ & $(.166)$ & $(.166)$ & $(.174)$ & $(.187)$ & $(.187)$ \\
\hline \multirow[t]{2}{*}{ 3. Five-year moving average } & -.286 & -.351 & -.354 & -.371 & -.426 & -.430 \\
\hline & $(.097)$ & $(.102)$ & $(.101)$ & $(.113)$ & $(.117)$ & $(.117)$ \\
\hline \multirow{2}{*}{$\begin{array}{l}\text { 4. Five-year moving average, } \\
\text { including only intended stayers }\end{array}$} & -.382 & -.461 & -.464 & -.486 & -.553 & -.554 \\
\hline & $(.102)$ & $(.108)$ & $(.108)$ & $(.119)$ & $(.123)$ & $(.123)$ \\
\hline \multicolumn{7}{|l|}{ Controls: } \\
\hline$($ Field $\times$ period $)$ interactions & No & Yes & Yes & No & Yes & Yes \\
\hline State of residence fixed effects & No & No & Yes & No & No & Yes \\
\hline
\end{tabular}

Notes: The standard errors are reported in parentheses. The regressions have 240 observations when using the 3-year cohort groups and 714 observations when using the 5-year moving average. All regressions are weighted by the total sampling weight for the field-cohort cell. The standard errors are adjusted for heteroscedasticity by using the HuberWhite correction. 


\section{Table 4. Sensitivity analysis (Coefficient of immigrant share)}

$\underline{\text { Sample }}$

1. Baseline, all natives

2. Male

3. Female

4. Academic employer

5. Non-academic employer

6. Received degree in 1971-1979

7. Received degree in 1981-1989

8. Received degree in 1991-1999

\begin{tabular}{lc}
\multicolumn{2}{c}{ Annual adjusted salary } \\
\hline $\begin{array}{l}\text { 3-year } \\
\text { cohort }\end{array}$ & $\begin{array}{c}\text { 5-year moving } \\
\text { average }\end{array}$ \\
-.496 & -.464 \\
$(.166)$ & $(.108)$ \\
-.452 & -.435 \\
$(.129)$ & $(.098)$ \\
-.821 & -.854 \\
$(.258)$ & $(.218)$ \\
-.388 & -.382 \\
$(.169)$ & $(.122)$ \\
-.366 & -.331 \\
$(.162)$ & $(.129)$ \\
-.641 & -.622 \\
$(.339)$ & $(.340)$ \\
-.459 & -.605 \\
$(.227)$ & $(.228)$ \\
-.803 & -1.249 \\
$(.412)$ & $(.430)$
\end{tabular}

Income earned last year

\begin{tabular}{|c|c|}
\hline $\begin{array}{l}\text { 3-year } \\
\text { cohort }\end{array}$ & $\begin{array}{c}\text { 5-year moving } \\
\text { average }\end{array}$ \\
\hline$\overline{-.623}$ & -.554 \\
\hline$(.187)$ & $(.123)$ \\
\hline-.515 & -.490 \\
\hline$(.150)$ & $(.118)$ \\
\hline-.778 & -.844 \\
\hline$(.272)$ & $(.222)$ \\
\hline-.475 & -.476 \\
\hline (.189) & $(.137)$ \\
\hline-.529 & -.479 \\
\hline$(.180)$ & $(.144)$ \\
\hline-.522 & -.305 \\
\hline$(.521)$ & $(.444)$ \\
\hline-.373 & -.537 \\
\hline$(.255)$ & $(.286)$ \\
\hline-1.309 & -1.884 \\
\hline$(.396)$ & $(.424)$ \\
\hline
\end{tabular}

Notes: The standard errors are reported in parentheses. The number of observations in each of the regressions using the 3-year cohort groups and 5-year moving average is: baseline: 240, 714; male: 240, 714; female: 217, 590;

academic employer: 238, 694; non-academic employer: 239, 708; the 1970s cohort: 65, 192; the 1980s cohort: 88 , 197; and the 1990s cohort: 88,198 . The reported regression coefficients come from the specification of the model that includes both field-period interactions and state-of-residence fixed effects. All regressions are weighted by the total sampling weight for the field-cohort cell. The standard errors are adjusted for heteroscedasticity by using the Huber-White correction. 


\section{Table 5. Factor price elasticities} (IV estimates)

Sample / measure of supply:

A. Natives

1. Three-year cohort

2. Five-year moving average

B. Immigrants

1. Three-year cohort

2. Five-year moving average

C. All workers

1. Three-year cohort

2. Five-year moving average
Adjusted annual salary

(1)

(2)

(3)

$$
-.227
$$

(.112)

$-.252$

(.073)

$\begin{array}{ll}-.259 & -.260 \\ (.125) & (.126) \\ -.288 & -.289 \\ (.081) & (.081)\end{array}$

\begin{tabular}{lll}
\multicolumn{3}{c}{ Income earned last year } \\
\hline$\underline{(1)}$ & $\underline{(2)}$ & $\underline{(3)}$ \\
-.275 & -.311 & -.306 \\
$(.129)$ & $(.142)$ & $(.141)$ \\
-.312 & -.341 & -.337 \\
$(.083)$ & $(.088)$ & $(.088)$
\end{tabular}

$\begin{array}{lll}-.348 & -.405 & -.423 \\ (.197) & (.220) & (.223) \\ -.373 & -.435 & -.454 \\ (.138) & (.150) & (.150)\end{array}$

$-.382$

$-.424$

$-.432$

$(.230)$

$(.238)$

$(.235)$

$-.451$

$-.497$

$-.504$

(.163)

(.168)

(.166)

$\begin{array}{lll}-.244 & -.277 & -.285 \\ (.125) & (.139) & (.140) \\ -.267 & -.306 & -.313 \\ (.080) & (.087) & (.088)\end{array}$

$-.302$

$-.328$

$-.329$

(.148) (.157)

$(.158)$

$-.330$

$-.361$

$-.362$

(.091)

(.096)

(.096)

Controls:

(Field $\times$ period) interactions

State of residence fixed effects

$\begin{array}{lll}\text { No } & \text { Yes } & \text { Yes } \\ \text { No } & \text { No } & \text { Yes }\end{array}$

Notes: The standard errors are reported in parentheses. The instrument is the log of the number of doctoral degrees awarded to foreign-born persons in a particular field-cohort group. The regressions in the native sample have 240 observations when using the 3 -year cohort groups and 714 observations when using the 5 -year moving average; the respective numbers in the immigrant sample are 235 and 684; and in the "all workers" sample, 240 and 717 . All regressions are weighted by the total sampling weight for the field-cohort cell. The standard errors are adjusted for heteroscedasticity by using the Huber-White correction. 


\section{Table 6. Summary statistics on post-doctorate appointments for native-born doctorates, 1993-2001}

$\underline{\text { Field }}$

Computer and information sciences

Mathematical sciences

Agricultural and food sciences

Biological sciences

Environmental life sciences

Health and related sciences

Chemistry, except biochemistry

Earth sciences, geology and oceanography

Physics and astronomy

Other physical sciences

Economics

Political science

Sociology and anthropology

Other social sciences

Psychology

Aerospace and related engineering

Chemical engineering

Civil and architectural engineering

Electrical, electronic engineering

Industrial engineering

Mechanical engineering

Other engineering

All fields

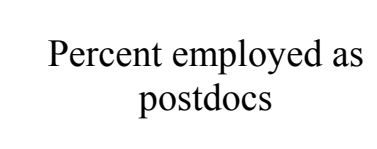

All Aged 40 or

persons

1.6

2.2

2.8

10.1

2.0

2.5

3.5

4.2

5.7

5.9

0.6

1.4

1.6

1.1

2.5

2.1

1.1

1.7

1.1

2.5

1.9

1.4

4.2
Mean annual salary, workers aged 40 or less (in $\$ 1,000 \mathrm{~s}$ )

Postdoctoral
appointment

58.2

42.8

34.8

34.2

34.3

35.8

35.7

40.9

41.3

41.4

47.0

40.2

34.3

44.3

32.4

40.7

45.5

45.4

45.2

47.2

47.8

39.5

36.0

65.9

Source: Survey of Doctoral Recipients, 1993-2001 waves. 


\section{Table 7. The impact of immigration on the probability of being employed as a postdoctoral fellow \\ (IV estimates)}

Sample / measure of supply:

A. Natives

1. Three-year cohort

2. Five-year moving average

B. Immigrants

1. Three-year cohort

2. Five-year moving average

C. All workers

1. Three-year cohort

2. Five-year moving average

\author{
All persons
}

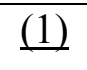

.383

$(.142)$

.423

(.086)

.640

$(.277)$

.667

(.170)

$\begin{array}{ll}.736 & .727 \\ (.321) & (.321) \\ .768 & .760 \\ (.197) & (.198)\end{array}$

.410

(.155)

.453

(.093)

.406

$(.153)$

.449

(.093)

(3)

40 years old or younger

$\begin{array}{lll}\underline{(1)} & \underline{(2)} & \underline{(3)} \\ 1.086 & 2.174 & 2.160 \\ (.302) & (.578) & (.569) \\ 1.182 & 2.333 & 2.316 \\ (.178) & (.337) & (.331)\end{array}$

$(.302)$

$(.578)$

$(.331)$

\section{(.569)}

569)

(.178) (.337)

$1.454 \quad 2.653$

(.665)

(1.184)

2.690

(1.198)

$\begin{array}{lll}1.705 & 3.184 & 3.227\end{array}$

(.445)

(.798)

(.806)

$\begin{array}{ccc}.441 & .475 & .470 \\ (.168) & (.185) & (.183) \\ .484 & .522 & .517 \\ (.102) & (.112) & (.111)\end{array}$

1.269

2.403

2.373

(.397)

$(.731)$

(.718)

$1.404 \quad 2.672$

2.642

(.102)

(.112)

(.235)

(.434)

(.427)

Controls:

(Field $\times$ period) interactions

State of residence fixed effects

$\begin{array}{lll}\text { No } & \text { Yes } & \text { Yes } \\ \text { No } & \text { No } & \text { Yes }\end{array}$

Notes: The standard errors are reported in parentheses. The instrument is the log of the number of doctoral degrees awarded to foreign-born persons in a particular field-cohort group. The regressions in the native sample (over all age groups) have 240 observations when using the 3 -year cohort groups and 714 observations when using the 5-year moving average; the respective numbers in the immigrant sample are 236 and 688; and in the "all workers" sample, 240 and 717. The regressions in the native sample (for workers under the age of 40 ) have 170 observations when using the 3-year cohort groups and 478 observations when using the 5-year moving average; the respective numbers in the immigrant sample are 158 and 434; the respective numbers in the "all workers" sample are 172 and 484 . All regressions are weighted by the total sampling weight for the field-cohort cell. The standard errors are adjusted for heteroscedasticity by using the Huber-White correction. 


\section{Table 8. Factor price elasticities for workers not in postdoctoral appointments (IV estimates)}

Sample / measure of supply

A. Native

2. Five-year moving average

B. Immigrant

1. Three-year cohort

2. Five-year moving average

C. All workers

1. Three-year cohort

2. Five-year moving average

Controls:

(Field $\times$ period) interactions

State of residence fixed effects
1. Three-year cohort

\begin{tabular}{cccccccc}
\multicolumn{3}{c}{ Adjusted annual salary } & & \multicolumn{3}{c}{ Income earned last year } \\
\cline { 1 - 2 } \cline { 6 - 7 } & $\underline{(1)}$ & $\underline{(2)}$ & $\underline{(3)}$ & & $\underline{(1)}$ & $\underline{(2)}$ & $\underline{(3)}$ \\
-.053 & -.074 & -.074 & & -.111 & -.132 & -.125 \\
$(.057)$ & $(.064)$ & $(.064)$ & & $(.077)$ & $(.085)$ & $(.084)$ \\
-.063 & -.088 & -.087 & & -.127 & -.152 & -.145 \\
$(.047)$ & $(.051)$ & $(.051)$ & & $(.058)$ & $(.062)$ & $(.062)$
\end{tabular}

$\begin{array}{llllll}.003 & -.032 & -.055 & -.042 & -.089 & -.125 \\ (.080) & (.088) & (.086) & (.121) & (.129) & (.128) \\ -.011 & -.046 & -.075 & -.107 & -.160 & -.198 \\ (.080) & (.083) & (.080) & (.104) & (.109) & (.108)\end{array}$

$\begin{array}{llllll}-.034 & -.055 & -.058 & -.089 & -.113 & -.110 \\ (.056) & (.063) & (.063) & (.081) & (.089) & (.089) \\ -.040 & -.065 & -.069 & -.109 & -.137 & -.135 \\ (.044) & (.047) & (.047) & (.058) & (.062) & (.062)\end{array}$

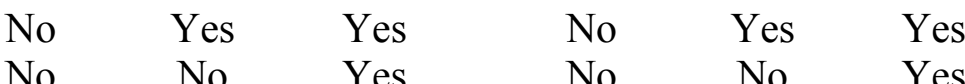

Notes: The standard errors are reported in parentheses. The instrument is the log of the number of doctoral degrees awarded to foreign-born persons in a particular field-cohort group. The regressions in the native sample have 240 observations when using the 3 -year cohort groups and 714 observations when using the 5 -year moving average; the respective numbers in the immigrant sample are 236 and 685; and in the "all workers" sample, 240 and 716 . All regressions are weighted by the total sampling weight for the field-cohort cell. The standard errors are adjusted for heteroscedasticity by using the Huber-White correction. 
Table 9. Predicted wage impact of the 1993-2001 immigrant influx, by field

\begin{tabular}{lccc} 
& $\begin{array}{c}\text { Immigrant supply } \\
\text { shock }\end{array}$ & $\begin{array}{c}\text { Predicted impact } \\
\text { on log salary }\end{array}$ & $\begin{array}{c}\text { Actual change in } \\
\text { log salary }\end{array}$ \\
\cline { 2 - 4 } Computer and information sciences & 0.364 & -0.095 & 0.216 \\
Mathematical sciences & 0.173 & -0.045 & 0.049 \\
Agricultural and food sciences & 0.206 & -0.054 & 0.081 \\
Biological sciences & 0.130 & -0.034 & 0.058 \\
Environmental life sciences & 0.022 & -0.006 & -0.041 \\
Health and related sciences & 0.095 & -0.025 & -0.084 \\
Chemistry, except biochemistry & 0.137 & -0.036 & 0.091 \\
Earth sciences, geology and oceanography & 0.109 & -0.028 & -0.038 \\
Physics and astronomy & 0.150 & -0.039 & 0.073 \\
Other physical sciences & 0.339 & -0.088 & 0.169 \\
Economics & 0.131 & -0.034 & 0.131 \\
Political science & 0.054 & -0.014 & -0.012 \\
Sociology and anthropology & 0.045 & -0.012 & -0.127 \\
Other social sciences & 0.071 & -0.018 & -0.050 \\
Psychology & 0.018 & -0.005 & -0.121 \\
Aerospace and related engineering & 0.203 & -0.053 & 0.110 \\
Chemical engineering & 0.213 & -0.055 & 0.036 \\
Civil and architectural engineering & 0.289 & -0.075 & 0.073 \\
Electrical, electronic engineering & 0.335 & -0.087 & 0.188 \\
Industrial engineering & 0.235 & -0.061 & 0.137 \\
Mechanical engineering & 0.369 & -0.096 & 0.115 \\
Other engineering & 0.223 & -0.058 & 0.078 \\
& & & \\
All fields & 0.139 & -0.036 & 0.052
\end{tabular}

Notes: The simulation uses the factor price elasticity reported in the third column of row 1 of Table 5 , or -.260 . The immigrant supply shock (within field) gives the ratio of the number of doctorates granted between 1993 and 2001 to the native stock in 1993 (where the native stock in 1993 is defined as the sum of the total number of doctorates granted to natives and the number of doctorates granted to foreign-born persons prior to 1993). 